\title{
Trends of Temperature and Signature of Solar Activity in Selected Stations in Nigeria
}

\author{
Christiana F. Olusegun ${ }^{*}$, Akeem B. Rabiu², Jared O. H. Ndeda ${ }^{3}$, Emmanuel C. Okogbue ${ }^{4}$ \\ ${ }^{1}$ Department of Physical and Chemical Sciences, Elizade University, Ilara-Mokin, Nigeria \\ ${ }^{2}$ Center for Atmospheric Research, National Space Research and Development Agency (NASRDA), Kogi State \\ University Campus, Anyigba, Nigeria \\ ${ }^{3}$ Department of Physics, Jomo Kenyatta University of Agriculture and Technology, Nairobi, Kenya \\ ${ }^{4}$ Department of Meteorology, Federal University of Technology, Akure, Nigeria \\ Email: ${ }^{*}$ christiana.olusegun@elizadeuniversity.edu.ng, ${ }^{*}$ chrystali2002@yahoo.co.uk
}

Received 25 December 2013; revised 20 January 2014; accepted 27 January 2014

Copyright (C) 2014 by authors and Scientific Research Publishing Inc.

This work is licensed under the Creative Commons Attribution International License (CC BY).

http://creativecommons.org/licenses/by/4.0/

(c) (i) Open Access

\section{Abstract}

This study investigates the variability and periodicity of minimum temperature, maximum temperature and sunspot number - a solar activity index in selected synoptic stations across Nigeria from 1946 to 2010. Annual and semiannual effect of solar activity on minimum temperature was observed in all the six stations. This was indicated in the occurrence of modal periodicities of 6month and 12-month observed across the six synoptic stations. The synoptic stations are Sokoto $\left(13.01^{\circ} \mathrm{N}, 5_{15}^{\circ} \mathrm{E}\right)$, Ilorin $\left(8.29^{\circ} \mathrm{N}, 4^{\circ} .35^{\circ} \mathrm{E}\right)$, Ikeja $\left(6.35^{\circ} \mathrm{N}, 3.20^{\circ} \mathrm{E}\right)$, Enugu $\left(6.28^{\circ} \mathrm{N}, 7^{\circ} 33^{\circ} \mathrm{E}\right)$, Port-Harcourt $\left(4.51^{\circ} \mathrm{N}, 7^{\circ} .01^{\circ} \mathrm{E}\right)$ and Maiduguri $\left(11.51^{\circ} \mathrm{N}, 13.05^{\circ} \mathrm{E}\right)$. Similarly, the trends of inter-decadal variability of minimum and maximum temperature show a non-uniformity increase over the analyzed period with a slight decrease before 1960 . The long term behavior of minimum and maximum temperature shows a warming rate which ranges from $0.1^{\circ} \mathrm{C} /$ decade to $0.2^{\circ} \mathrm{C} /$ decade across the six stations except for maximum temperature at Ilorin and minimum temperature at Sokoto which is at $-0.2^{\circ} \mathrm{C} /$ decade and $0.3^{\circ} \mathrm{C} /$ decade respectively.

\section{Keywords}

Trends; Temperature; Solar Activity; Periodicity

\section{Introduction}

The amount of energy reaching the earth from the sun is the main driver of weather and climate. Temperature

"Corresponding author. 
differences from day to night and from season to season are the consequences of the intensity of sunlight falling to the surface and into the earth's atmosphere.

The impact of solar activity on Earth's terrestrial environment is propagated from the heliosphere via the interplanetary medium to the lower atmosphere which has troposphere at its lower end. However, sunspots are the most easily observed features of the solar photosphere, while at the same time they are important manifestations of solar activity [1].

A full understanding of the influence of solar variability on the Earth's climate requires knowledge of the short and long term solar variability, solar-terrestrial interactions, and the mechanisms determining the response of the Earth's climate system to these interactions [2]. Therefore, it is important to understand the solar terrestrial interaction, including climatology and weather, within the context of Earth's connection to Sun's activity [3] [4].

Nigeria's climate is characterized by strong latitudinal zones becoming progressively drier and hotter as one travels from the coast to the north. Temperatures throughout Nigeria are generally high; diurnal variations are much more pronounced than seasonal variations. Although average temperatures vary little from coastal to inland areas, inland areas especially in the northeast have greater extremes.

The aim of this study is to improve knowledge on the potential localized effect of solar activity on temperature in selected cities across Nigeria. This was achieved by investigating the trend pattern of temperature, a climatic variable with respect to sunspot number-a solar index. Similarly, attribution of periodic variation of temperature to solar effect is also investigated.

\section{Study Area}

Nigeria is located approximately within latitude 4 degrees and 14 degrees north of the equator and between 2 degrees and 14 degree east of the Greenwich Meridian (Figure 1). It has a unique warm tropical climate system with relatively high temperatures all year round. The different climate varies from humid equatorial in the coastal areas, sub-humid in the center and semiarid climates in the north. Nigeria has two seasons (dry and wet seasons) annually. These two seasons are directly under the influence of the interaction between the relatively warm and moist tropical marine air mass and the cool relatively stable tropical continental air mass.

The six synoptic stations chosen in this study takes into account the major climatic zones in the country. Sokoto $\left(13.01^{\circ} \mathrm{N}, 5.15^{\circ} \mathrm{E}\right)$ and Maiduguri $\left(11.51^{\circ} \mathrm{N}, 13.05^{\circ} \mathrm{E}\right)$ are in the highland semi-arid zone of Nigeria. Ilorin $\left(8.29^{\circ} \mathrm{N}, 4.35^{\circ} \mathrm{E}\right)$ and Enugu $\left(6.28^{\circ} \mathrm{N}, 7.33^{\circ} \mathrm{E}\right)$ are from the sub-humid zone while Ikeja $\left(6.35^{\circ} \mathrm{N}, 3.20^{\circ} \mathrm{E}\right)$ and Port Harcourt $\left(4.51^{\circ} \mathrm{N}, 7.01^{\circ} \mathrm{E}\right)$ are in the lowland warm and humid forest zone.

A brief description of some of the selected cities across Nigeria whose data is utilized in this research is given below:

Sokoto $\left(13.01^{\circ} \mathrm{N}, 5.15^{\circ} \mathrm{E}\right)$ is one of the cities in the Sahel region of Nigeria. The influence of increase in temperature has resulted in increased evapotranspiration, drought as well as desertification [5]. Sokoto is one of the hottest cities in Nigeria with maximum daytime temperature ranging between $35^{\circ} \mathrm{C}$ and $40^{\circ} \mathrm{C}$ and an annual average temperature of about $38^{\circ} \mathrm{C}$. February to April is the warmest months during which daytime maximum temperature can reach up to about $45^{\circ} \mathrm{C}$.

Ilorin $\left(8.29^{\circ} \mathrm{N}, 4.35^{\circ} \mathrm{E}\right)$ is located in the transition zone between the dry savanna of northern Nigeria and deciduous woodlands of southern Nigeria [6].The climate of Ilorin is humid tropical type and is characterized by both wet and dry seasons. The temperature ranges between $33^{\circ} \mathrm{C}$ and $34^{\circ} \mathrm{C}$ from November to January while from February to April the temperature is between $34.6^{\circ} \mathrm{C}$ and $37^{\circ} \mathrm{C}$ [7].

Ikeja $\left(6.35^{\circ} \mathrm{N}, 3.20^{\circ} \mathrm{E}\right)$ is located in the South Western region of Nigeria. It is a coastal area with a characteristic warm humid climate. The three major wind currents that influence the climate of this area are the maritime tropical (mT) air mass, the continental tropical (cT) air mass and the equatorial easterlies [8] [9].

Port Harcourt $\left(4.51^{\circ} \mathrm{N}, 7.01^{\circ} \mathrm{E}\right)$ is a coastal city located in the Niger Delta region of Nigeria. It falls within the humid tropical rain forest belt of Southeastern Nigeria. It has two seasons, the wet season and the dry season. During the wet and dry seasons the mean temperature varies from about $20.30^{\circ} \mathrm{C}$ to about $32.16^{\circ} \mathrm{C}$ respectively.

\section{Methodology}

Data Analysis

Monthly data of maximum temperature and minimum temperature were obtained from The Nigerian Meteorological Agency (NIMET), Oshodi, Lagos Nigeria. The data were obtained for six weather stations representing 


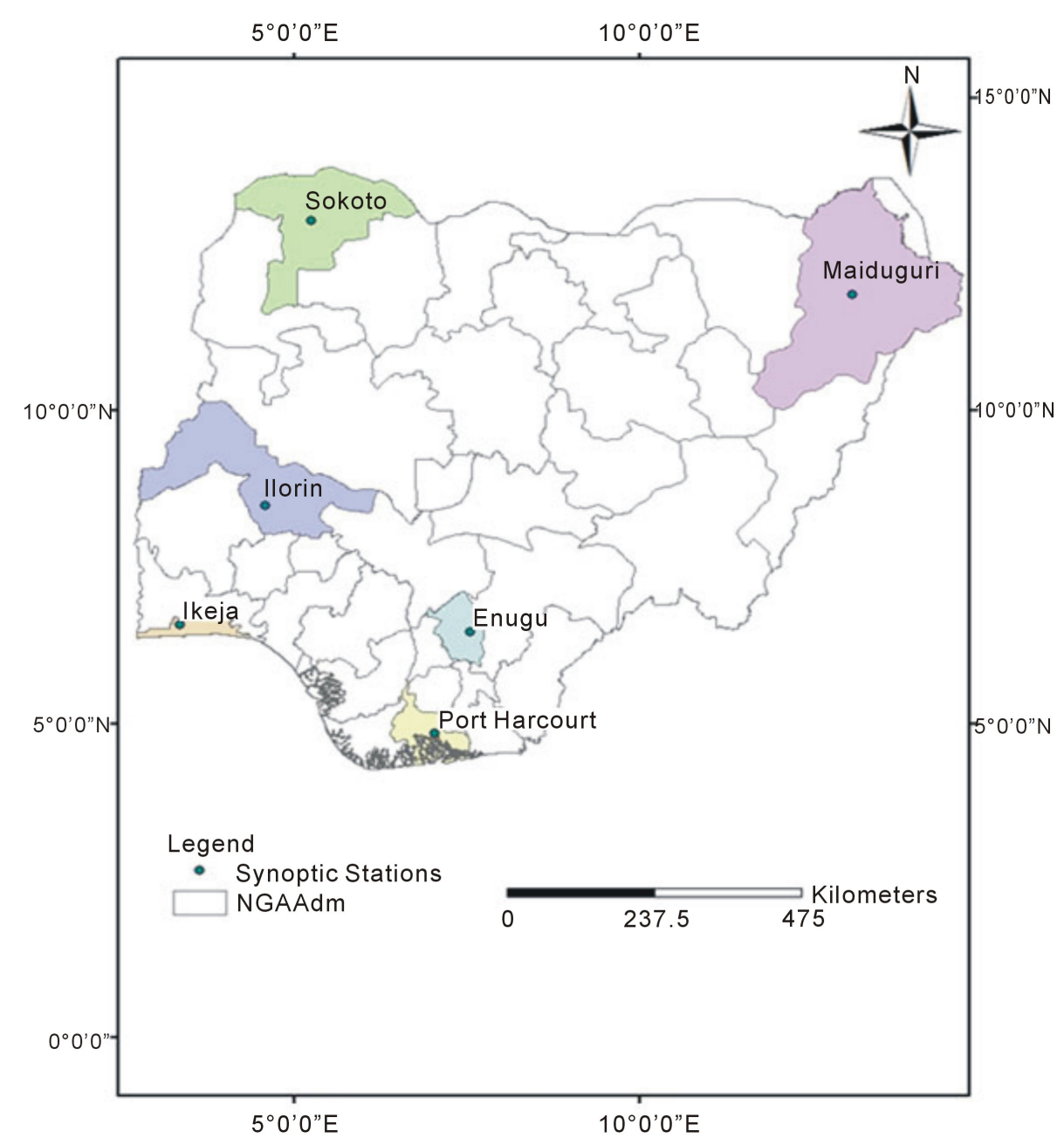

Figure 1. Map of Nigeria showing the synoptic stations used in this study.

the three main climatic zones (humid, sub-humid and semi-arid) within Nigeria for the period 1946-2010 (65 years). They are Sokoto $\left(13.01^{\circ} \mathrm{N}, 5.15^{\circ} \mathrm{E}\right)$, Ilorin $\left(8.29^{\circ} \mathrm{N}, 4.35^{\circ} \mathrm{E}\right)$, Ikeja $\left(6.35^{\circ} \mathrm{N}, 3.20^{\circ} \mathrm{E}\right)$, Enugu $\left(6.28^{\circ} \mathrm{N}\right.$, $\left.7.33^{\circ} \mathrm{E}\right)$ Port Harcourt $\left(4.51^{\circ} \mathrm{N}, 7.01^{\circ} \mathrm{E}\right)$ and Maiduguri $\left(11.51^{\circ} \mathrm{N}, 13.05^{\circ} \mathrm{E}\right)$. The solar index used was sunspot number (SSN) from 1946-2010 obtained from the National Geophysical Data Center (NGDC), Boulder, Colorado, USA. Missing monthly data was filled up by taking the means of the monthly value of the two preceding and following years. The linear trends in the climate time series between the years 1946-2010 were calculated by means of least-square linear fitting. Time series anomalies of temperature from 1951-2010 were obtained as deviations to the annual mean of 1981-2010. The relationships between time series of temperature and sunspot number were analyzed by means of parametric correlations. The statistical significance of the trend and correlation was estimated with the t-student test. T-test is preferentially used on data that is not serially correlated or seasonally cyclic or skewed. In order to test the confidence on the regression trend, it is important to set the confidence limits on the slope of the regression line. In this analysis, the statistical significance in the trend and correlation coefficients are considered significance only at least at 95\% level. Finally, the periodicity of temperature for each of the six meteorological stations was analyzed.

\section{Results and Discussion}

The annual variation of minimum temperature, maximum temperature is compared to the annual variation of sunspot number in all the six meteorological stations under consideration in this research. This is presented in Figure 2. A significant decreasing trend of -7.8 /decade was obtained for sunspot number while an increasing 

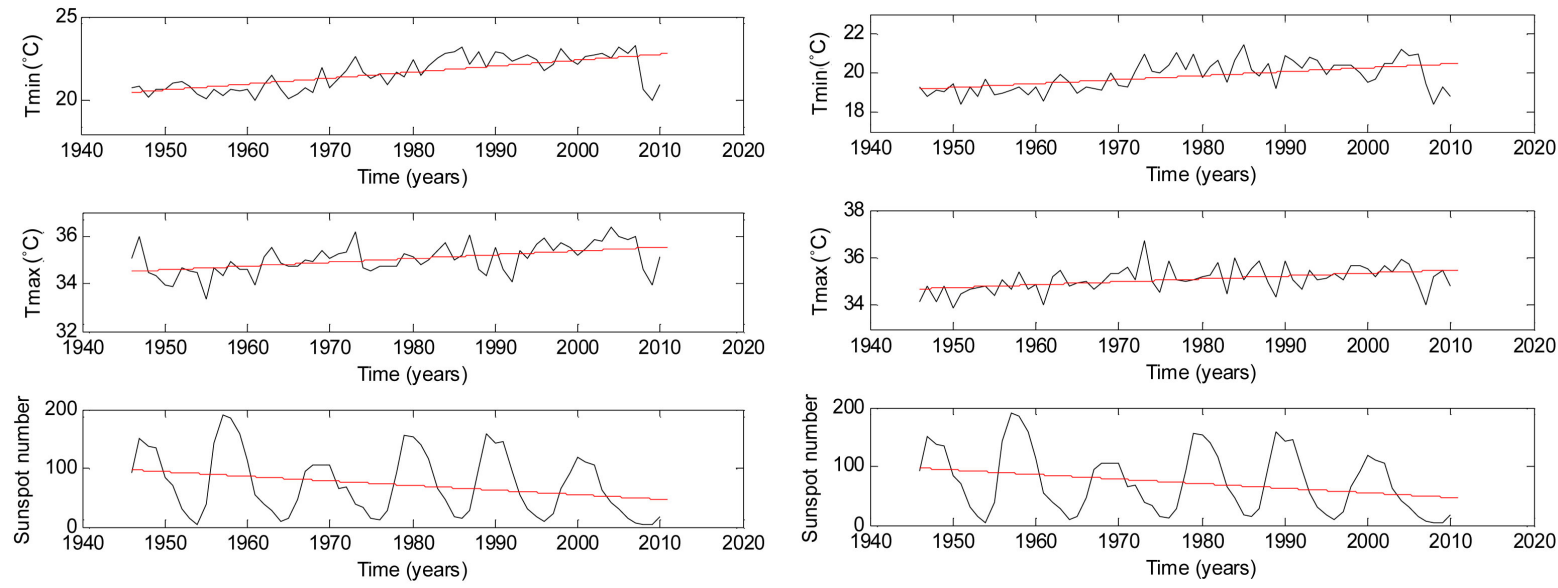

(a)

(b)
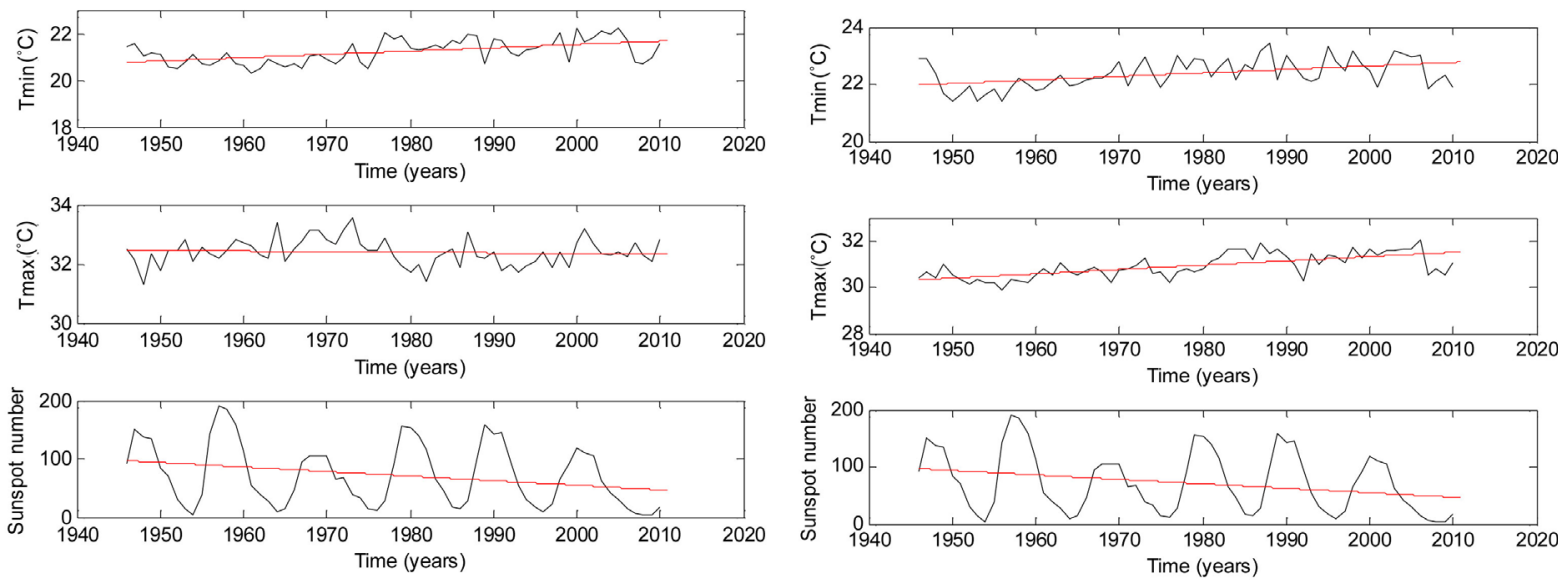

(c)

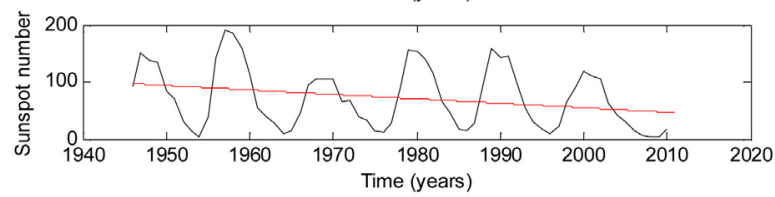

(d)
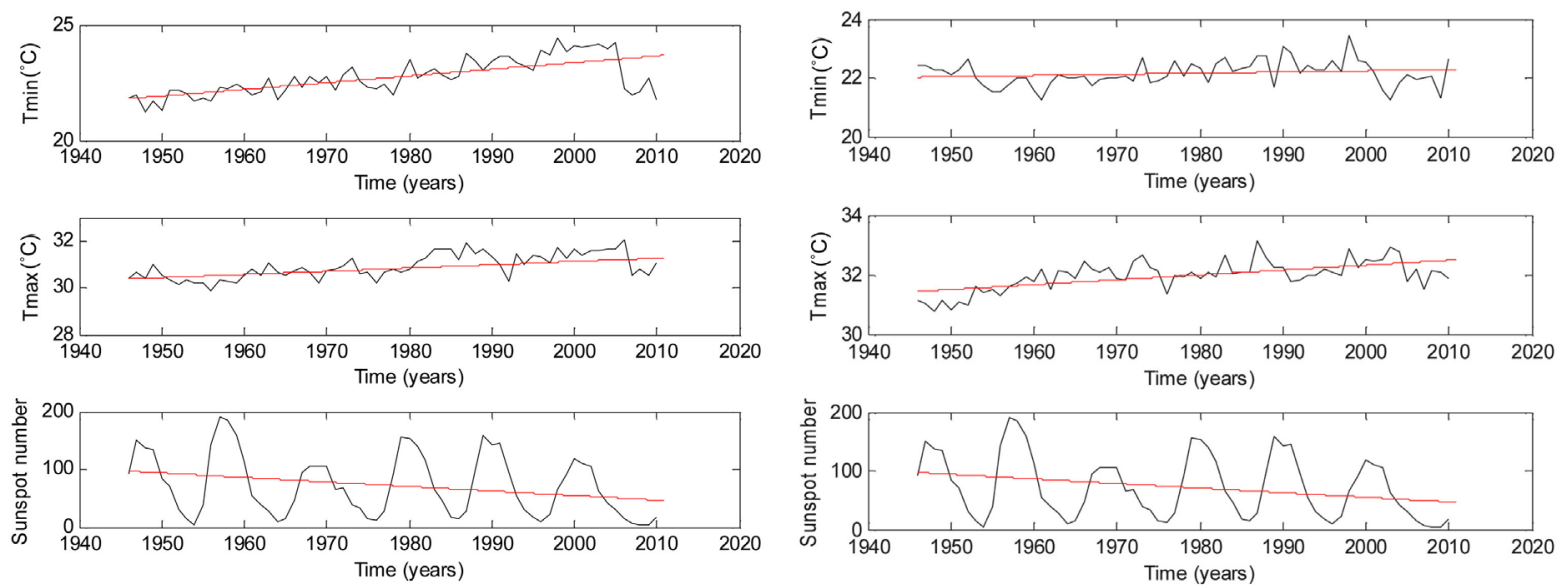

(e)

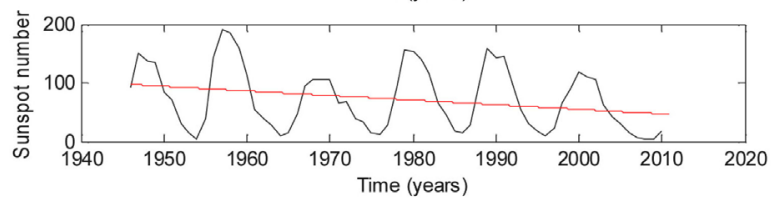

(f)

Figure 2. Annual variation of minimum temperature, maximum temperature and sunspot number at (a) Sokoto; (b) Maiduguri; (c) Ilorin; (d) Port Harcourt; (e) Ikeja; and (f) Enugu from 1946-2010.

trend of $0.18^{\circ} \mathrm{C} /$ decade, $0.16^{\circ} \mathrm{C} /$ decade, $0.13^{\circ} \mathrm{C} /$ decade, $0.12^{\circ} \mathrm{C} /$ decade, $0.15^{\circ} \mathrm{C} /$ decade was obtained for maximum temperature at Port Harcourt, Enugu, Ikeja, Maiduguri and Sokoto respectively between the years 1946 2010. However, at Ilorin a slight decreasing trend of $-0.02^{\circ} \mathrm{C} / \mathrm{decade}$ was observed. The long-term behavior of 
maximum and minimum temperature time series are similar to the global increase in mean air temperature, although the rate of warming in the selected cities across Nigeria is approximately twice the global mean surface temperatures which have risen by 0.074 /decade over the last century [10].

Figure 3 shows the variation of annual minimum temperature anomalies in Sokoto, Ikeja, Ilorin and Enugu between the years 1951-2010 relative to the 1981-2010 base period. This base period was chosen in order to comply with the recommended World Meteorological Organization (WMO) Policy, which suggests using the latest decade for the 30-year average. Minimum temperature anomalies at Ikeja, Ilorin, Enugu and Sokoto all show an increasing rate of $0.35^{\circ} \mathrm{C}, 0.35^{\circ} \mathrm{C}, 0.12^{\circ} \mathrm{C}$ and $0.37^{\circ} \mathrm{C} /$ decade respectively although a decreasing trend of $-0.1 /$ decade is observed in sunspot anomalies. This shows an inverse relationship between solar activity and temperature. However, the parametric correlation carried out between temperature (maximum and minimum) and sunspot number (SSN) at each of the six synoptic stations in Tables 1 and 2 shows that no correlation exists between temperature and solar activity. This implies that the increasing trend of temperature observed cannot be attributed to the influence of solar activity. The trend pattern of the temperature anomalies in all the six meteorological stations also shows a non-uniform increase from 1951 to 2010 as shown in Figure 3. However, it is worthy of note that a slight decrease is observed in the temperature pattern before 1970s while almost all the warming is observe after 1970s.

It can be observed from the periodicity analysis of minimum temperature in Figure 4 the dominant occurrence of semiannual and annual cycle effects. Semiannual and annual cycle appears to be the strongest and most significant periodicity in all the stations. This may be attributed to geomagnetic effect. It has long been recognized that geomagnetic activity exhibits this periodicities [11] [12] with the greatest activity near equinoxes
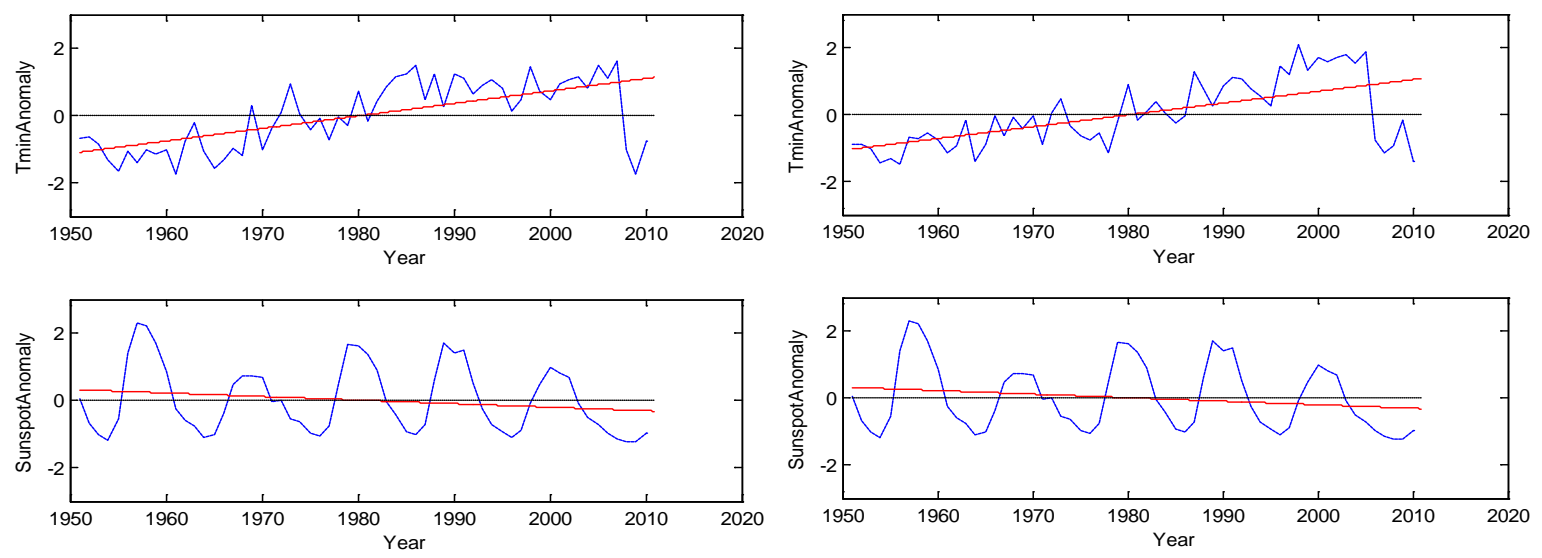

(a)
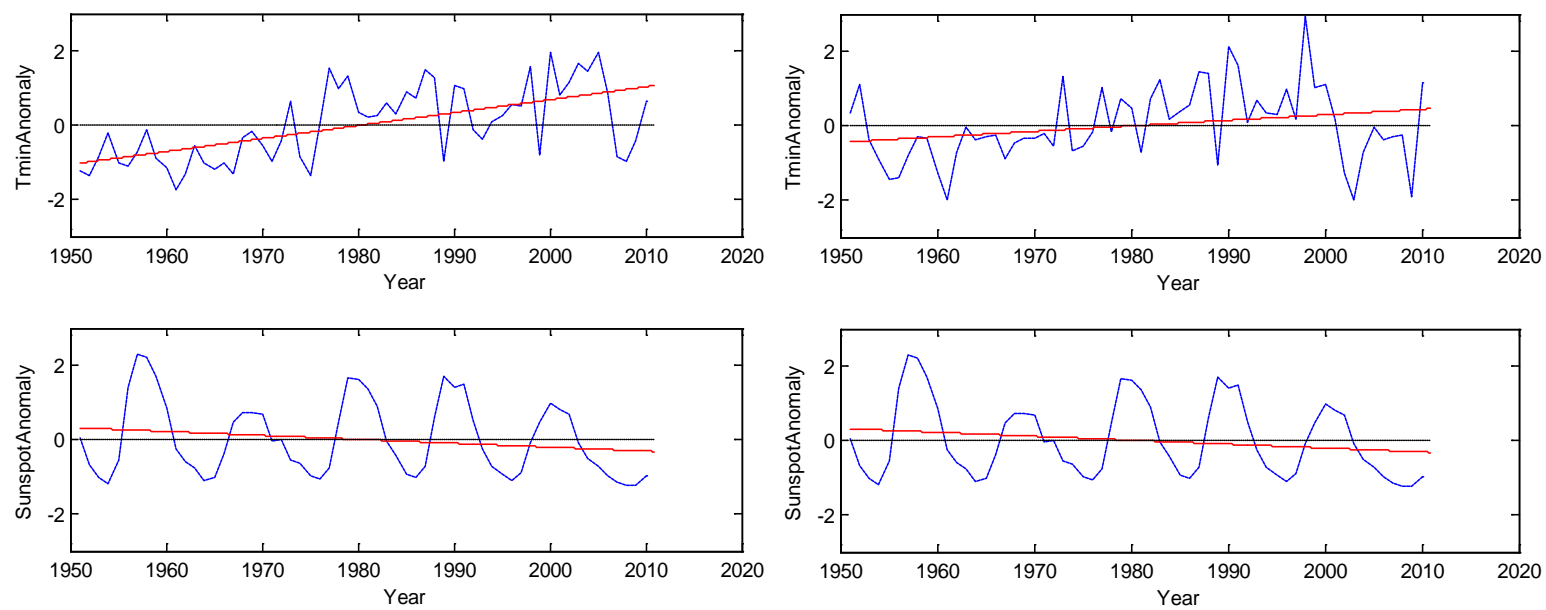

(c)

(d)

Figure 3. Annual minimum temperature and sunspot anomalies for the period 1951-2010 ( $\left.{ }^{\circ} \mathrm{C}\right)$, at (a) Sokoto; (b) Ikeja; (c) Ilorin; and (d) Enugu expressed as departures from 1981-2010 average. 

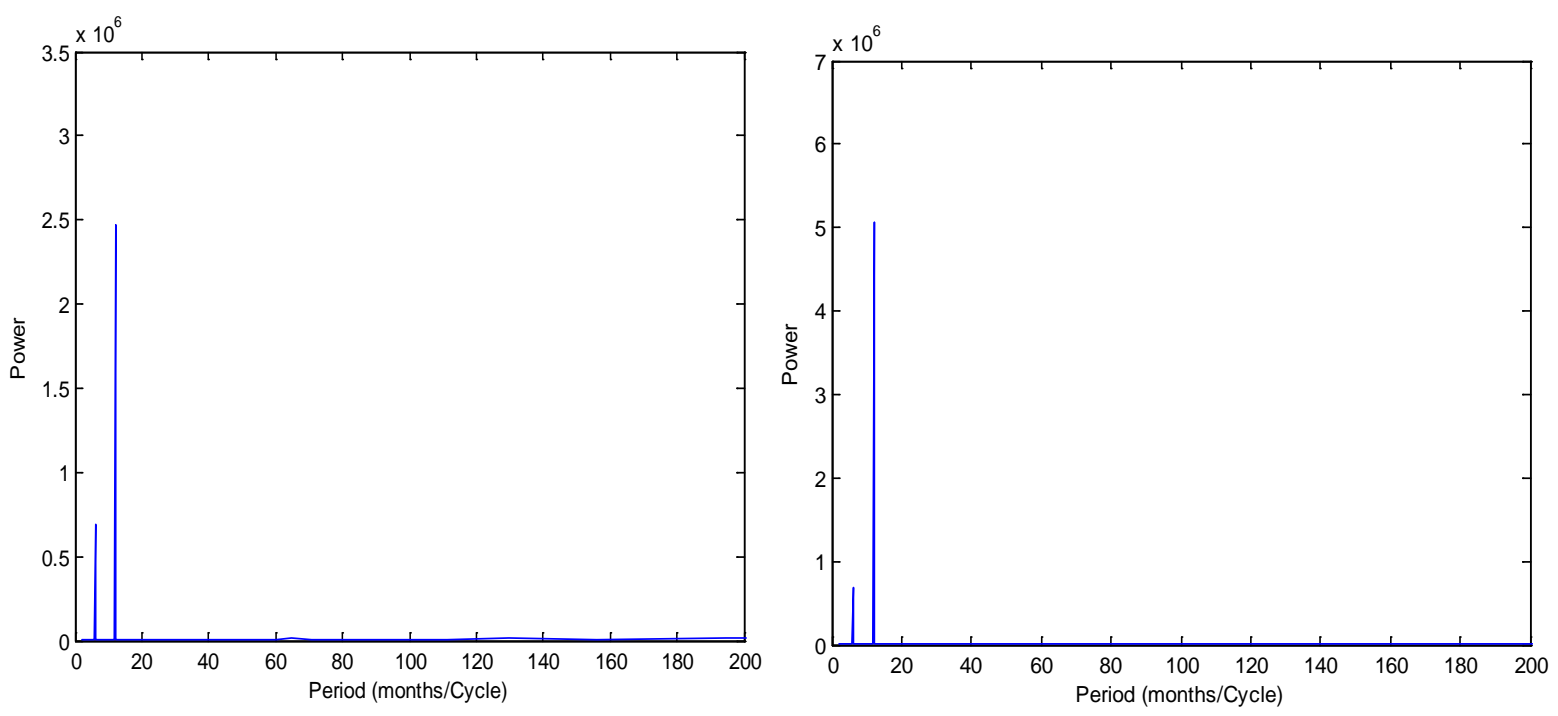

(a)

(b)
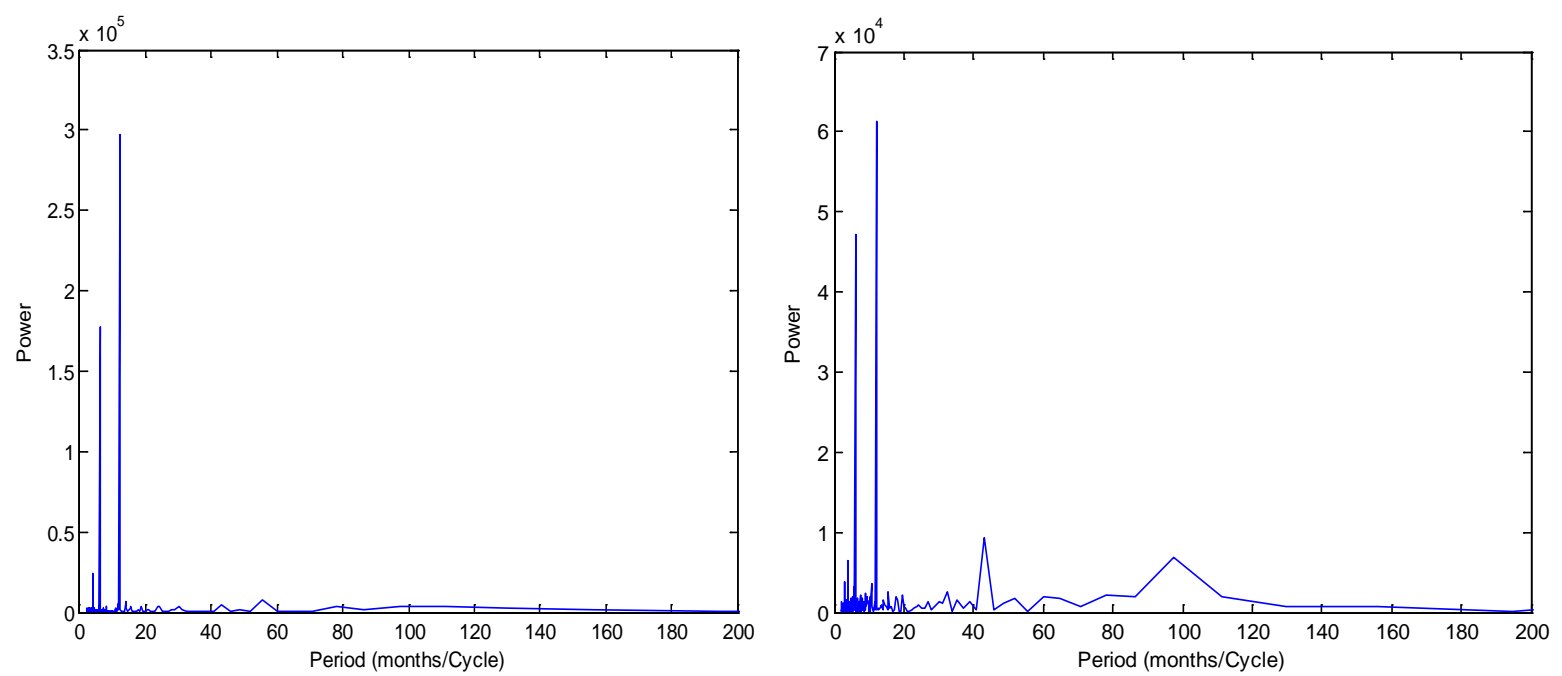

(c)

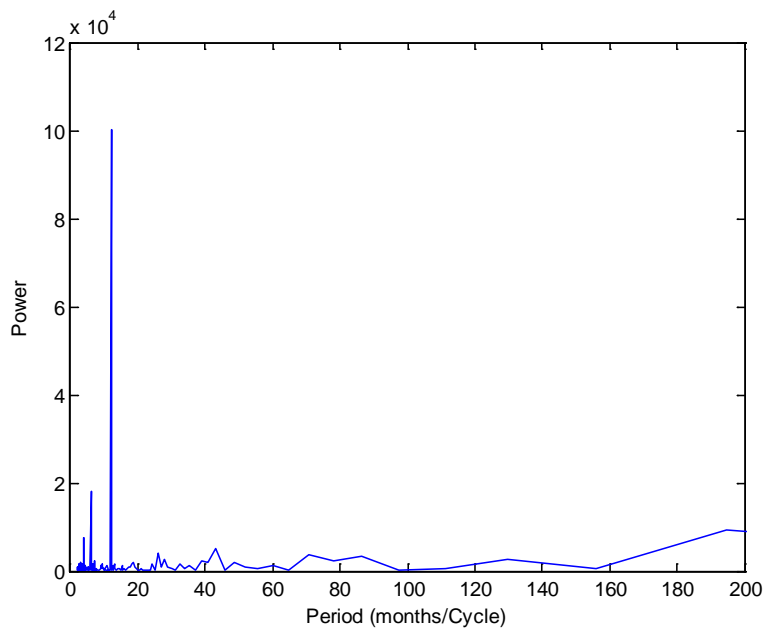

(d)

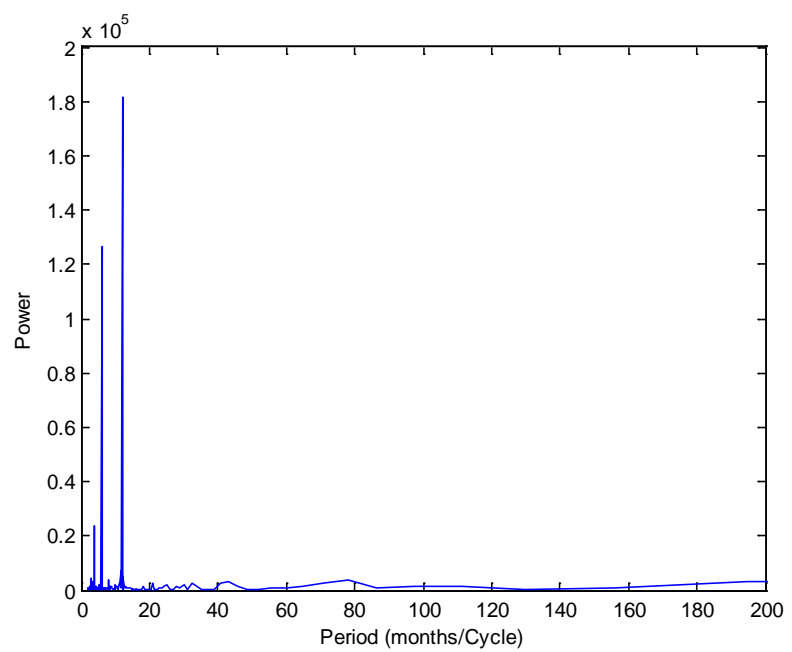

(f)

Figure 4. Periodicity of minimum temperature at (a) Sokoto; (b) Maiduguri; (c) Ilorin; (d) Port Harcourt; (e) Ikeja; and (f) Enugu. 
Table 1. Cross correlation between minimum temperature and solar activity across selected stations in Nigeria.

\begin{tabular}{cccccccc}
\hline & SSN & Sokoto & Maidu & Ilorin & Ikeja & Port & Enugu \\
\hline SSN & 1.00 & & & & & & \\
Sokoto & -0.01 & 1.00 & & & & & \\
Maidu & 0.00 & 0.89 & 1.00 & & & & \\
Ilorin & 0.07 & 0.18 & 0.16 & 1.00 & & & \\
Ikeja & 0.01 & 0.21 & 0.03 & 0.12 & 1.00 & & \\
Port & 0.01 & 0.56 & 0.49 & 0.16 & 0.45 & 1.00 & \\
Enugu & 0.01 & 0.60 & 0.55 & 0.20 & 0.36 & 0.62 & 1.00 \\
\hline
\end{tabular}

Table 2. Cross correlation between maximum temperature and solar activity across selected stations in Nigeria.

\begin{tabular}{ccccccc}
\hline & SSN & Sokoto & Maidu & Ilorin & Ikeja & \\
\hline SSN & 1.00 & & & & & \\
Sokoto & 0.01 & 1.00 & & & \\
Maidu & -0.03 & 0.76 & 1.00 & & & \\
Ilorin & -0.06 & 0.45 & 0.35 & 1.00 & & \\
Ikeja & -0.04 & 0.41 & 0.32 & 0.86 & 0.00 & 1.00 \\
Port & -0.07 & 0.36 & 0.26 & 0.80 & 0.86 & 0.86 \\
Enugu & -0.06 & 0.40 & 0.29 & 0.90 & 0.00 & 1.00 \\
\hline
\end{tabular}

(March 22nd and September 22nd). Gazis et al. (1995) [13] and Gazis (1996) [14] suggest that these variations must originate quite close to the Sun, probably in the Solar Wind source region.

\section{Conclusion}

The recent climate change in Nigeria may not be attributed to solar activity. However, influence of geomagnetic effect on temperature has been demonstrated at Sokoto, Maiduguri, Ilorin, Port Harcourt, Ikeja and Enugu in periodicity of 6-month/cycle and 12-month/cycle. This provides an evidence of solar terrestrial connection in the earth's atmosphere and has an important effect on communication and navigation systems.

\section{References}

[1] Gyori, L., Baranyi, T., Turmon, M. and Pap, J.M. (2004) Study of Differences between Sunspot Area Data Determined from Ground-Based and Space-Borne Observations. Advances in Space Research, 34, 269-273. http://dx.doi.org/10.1016/j.asr.2004.02.009

[2] Rind, D. (2002) The Sun's Role in Climate Variations. Science, 296, 673-678. http://dx.doi.org/10.1126/science.1069562

[3] Tobiska, W.K., Woods, T., Eparvier, F., Viereck, R., Floyd, L., Bouwer, D., Rottanman, G and White, O.R. (2000) The SOLAR2000 Empirical Solar Irradiance Model and Forecast Tool. Journal of Atmospheric and Solar Terrestrial Physics, 62, 1233-1250. http://dx.doi.org/10.1016/S1364-6826(00)00070-5

[4] Rabiu, A.B. (2004) Semiannual Variation of Geomagnetical Activity AK Index and its Response to Solar Activity. Zuma Journal of Pure and Applied Sciences (ZJPAS), 6, 40-47

[5] Odjugo, P.A. and Ikhuoria, A.I. (2003) The Impacts of Climate Change and Anthropogenic Factors on Desertification in the Semi-Arid Region of Nigeria. Global Journal of Environmental Science, 2, 118-126.

[6] Jimoh, H.I. (2003) Erosion Tolerance Range of Land Use Surfaces: Implication on Land Resource Use and Management Techniques in Ilorin Nigeria. International Journal of Environmental Studies, 60, 446.

[7] University of Ilorin (1982). Ilorin Atlas. Ilorin University Press, Ilorin.

[8] Ojo, O. (1977) Climates of West Africa. Heineman Publishers, Ibadan.

[9] Iloeje, N.P. (1981) A New Geography of Nigeria. New Revised Edition, Longman Publishers, London.

[10] Trenberth, K.E., et al. (2007) Observations: Surface and Atmospheric Climate Change Climate Change 2007-The Physical Science Basis: Working Group I Contribution to the Fourth Assessment Report of the IPCC. In: Solomon, S., Qin, D., Manning, M., Chen, Z., Marquis, M.C., Averyt, K.B., Tignor, M. and Miller, H.L., Eds., Cambridge Univer- 
sity Press, Cambridge.

[11] Russell, C.T. and Mcpherron, R.L. (1973) The Magnetotail and Substorms. Space Science Reviews, 15, 205. http://dx.doi.org/10.1007/BF00169321

[12] Szabo, A., Lepping, R. and King, J. (1995) Magnetic Field Observations of the 1.3-Year Solar Wind Oscillation. Geophysical Research Letters, 22, 1845-1848. http://dx.doi.org/10.1029/95GL01737

[13] Gazis, P.R., Richardson, J.D. and Paularena, K.I. (1995) Long Term Periodicity in Solar Wind Velocity during the Last Three Solar Cycles. Geophysical Research Letters, 22, 1165-1168. http://dx.doi.org/10.1029/95GL01017

[14] Gazis, P.R. (1996) Long Term Enhancements in the Solar Wind Speeds. Journal of Geophysical Research, 101, 415424. http://dx.doi.org/10.1029/95JA02638 